\title{
Laparoscopic Management of Non-palpable Testes: Ten Year Experience
}

\author{
Ele Gelmeyen Testisin Laparoskopik Yönetimi: On Yıllık Deneyim
}

\author{
(1) Günay Ekberli1, (1) Ufuk Ateş², (1) Aynur Gurbanova2, (1) Meltem Bingöl Koloğlu22, (1) Aydın Yağmurlu², (1) Murat Çakmak², \\ (D) Gülnur Göllü2 \\ ${ }^{1}$ Adana City Hospital, Clinic of Pediatric Urology, Adana, Turkey \\ ${ }^{2}$ Ankara University Faculty of Medicine, Department of Pediatric Surgery Division, Ankara, Turkey
}

\section{Abstract}

Objectives: Management of non-palpable testes is still one of the controversial topics of pediatric surgery. Laparoscopic exploration has been characterized as a gold standard in the diagnosis and management of undescended testes in recent years. In this study, we aimed to share our experience of diagnostic laparoscopy in non-palpable testes.

Materials and Methods: Seventy-three patients with non-palpable testes diagnosis, who were treated in the clinic between June 2006 and December 2017, were included in the study. Diagnostic laparoscopy was applied to all patients. According to findings determined during diagnostic laparoscopy, the next step of non-palpable testes management was planned. Age at presentation, affected side, operative techniques and results were recorded.

Results: The age of the children ranged from 6 to 197 months. The median age of patients was 46.7 months. The mean period of clinical follow-up was 19 months, ranging from 1 to 96 months. Laterality of non-palpable testes was determined through physical examination and confirmed via diagnostic laparoscopy. Sixty-six patients had unilateral non-palpable testes: Twenty-five testicular units were right-sided and 41 testicular units were left-sided. Other seven patients had bilateral non-palpable intra-abdominal testes.

Conclusion: Despite controversies and different advised techniques in the management of non-palpable testes, laparoscopy remains to be important. Laparoscopic assistance in the management of non-palpable testes not only leads to determination of localization and decision of next step procedure, but also helps to avoid unnecessary surgical attempts.

Key Words: Non-palpable Testes, Children, Diagnostic Laparoscopy

\section{$\ddot{0} z$}

Amaç: Palpe edilemeyen testis yönetimi hala çocuk cerrahisinin tartışmalı konularından biridir. Son yıllarda laparoskopik eksplorasyon palpe edilemeyen testis tanı ve tedavisinde altın standart olarak karakterize edilmektedir. Bu çalışmada ele gelmeyen testiste tanısal laparoskopi deneyimimizi paylaşmayı amaçladık.

Gereç ve Yöntem: Çalışmaya Haziran 2006 - Aralık 2017 tarihleri arasında kliniğimizde ele gelmeyen testis tanısı ile tedavi edilen 73 hasta dahil edilmiştir. Tüm hastalara tanısal laparoskopi uygulandı. Tanısal laparoskopi sonucunda edinilen bilgilere istinaden ele gelmeyen testis tedavisinin bir sonraki basamağı planlandı. Tanı yaşı, etkilenen taraf, ameliyat tekniği ve sonuçlar kaydedildi.

Bulgular: Hastaların yaş aralığı 6-197 ay idi. Ortanca yaş 46,7 ay idi. Klinik takip süresi 1-96 ay arasında ve ortalama 19 ay idi. Ele gelmeyen testis yerleşimi fizik muayene ile belirlenmiş olup, tanısal laparoskopi ile teyit edilmiştir. Yirmi beş testis sağ ve 41 testis sol olmak üzere 66 hastada tek taraflı inmemiş testis vardı. Geri kalan 7 hastada bilateral intra-abdominal testis vardı.

Sonuç: Ele gelmeyen testis yönetimindeki tartışma ve birçok farklı öneriye rağmen laparoskopinin önemi sebat etmektedir. Laparoskopi yardımlı ele gelmeyen testis yönetimi sadece testis lokalizasyonunu belirleme ve bir sonraki basamağın planlamasına yardımcı olmakla kalmayıp gereksiz cerrahi müdahaleyi de önlemektedir.

Anahtar Kelimeler: Ele Gelmeyen Testis, Çocuk, Tanısal Laparoskopi

Address for Correspondence/Yazışma Adresi: Günay Ekberli,

Adana City Hospital, Clinic of Pediatric Urology, Adana, Turkey

Phone: +90 5351056110 E-mail: gnyekbrl@yahoo.com ORCID ID: orcid.org/0000-0002-0021-5998

Received/Geliş Tarihi: 18.03.2021 Accepted/Kabul Tarihi: 25.06.2021

๑Copyright 2021 Ankara University Faculty of Medicine

Journal of Ankara University Faculty of Medicine is published by Galenos Publishing House.

All content are under CC BY-NC-ND license. 


\section{Introduction}

Crypthorchidism or undescended testes (UDT) is one of the problems of male reproductive system mainly detected in childhood. UDT occurs approximately in 3\% of full-term newborns and $21 \%$ of premature newborns (1-4). Incidence of UDT by 1 year of age is $1 \%$ (5). More than 70\% of UDT are palpable in the groin and 90\% of these boys is associated with hernia $(1,6)$. Remain $30 \%$ of UDT cases cannot be localized by physical exam. For testes that are non-palpable 30\% will be found in inguinoscrotal area, 55\% will be found in abdominal area and $15 \%$ will be vanishing or absent (7). The etiology of the vanishing testes thought to be vascular insufficiency, especially torsion $(8,9)$. One of the etiologic factors of non-palpable testes is agenesis of the testes. So, in the condition of non-palpable testes patient could be categorized in one of the groups like agenesis, vanishing testes, intra-abdominal testes and inguinal testes. With the advancement in laparoscopic techniques and instruments, laparoscopic orchidopexy has become a standard procedure in the management of non-palpable UDT. Despite various more less invasive tools for determination of nonpalpable testes none of these tools provide comparable success to laparoscopy (5). Aim of the study to share ten-year experience of laparoscopic management of non-palpable testes in light of literature.

\section{Materials and Methods}

The patients' recorded medical data were analyzed retrospectively. The study was performed in adherence to the Declaration of Helsinki. Ankara University Faculty of Medicine, Clinical Research Ethics Committee approval was provided for the study (approval no: 09-723-1). Seventy-three patients with complaints of absent testes were examined and children with non-palpable testes included in the study. Children examined as out patients. None of the patients undergo human chorionic gonadotrophin stimulation test. Second examination was done after receiving of general anesthesia to exclude palpability of testes. Those with non-palpable were subjected to operative laparoscopy. Because of its superiority in both diagnosis and treatment we prefered diagnostic laparoscopy instead of magnetic resonance imaging in all out patients. According to laparoscopic exploration following surgical procedure was planned. Camera port (4 mm) introduced from umbilicus by open approach and $\mathrm{CO}^{2}$ insufflation continued till $10 \mathrm{mmHg}$ of pneumoperitoneum. After visualization of abdominal cavity subsequent trocars $(5 \mathrm{~mm}$ ) were placed in right or left quadrant if needed. After placement of trocars diagnostic laparoscopy was done to all quadrants of abdomen in all children. Both inguinal rings were inspected and localizations of testes were determined. High localized testes categorized as testes below internal inguinal ring more than $2 \mathrm{~cm}$. Blind-ended vas deference defined as absence of testicular tissue at the end of the spermatic cord. Preoperative and postoperative clinical findings of all patients with non-palpable testes were recorded.

Patients categorized into three groups. Group 1: Patients treated with one-stage procedure $(n=61)$. Group 2: Patients treated with two-stage procedure $(n=11)$. Group 3: Patients treated with three-staged procedure $(n=1)$.

\section{Results}

The age of the children ranged from 6 to 197 months. The median age of patients was 46.7 months. The mean period of clinical follow-up was 19 months, ranging from 1 to 96 months. Laterality of non-palpable testes determined by physical examination and approved by diagnostic laparoscopy. Sixtysix patients had a unilateral non-palpable testes: Twenty-five testicular units were right-sided and 41 testicular units were left sided. Remain seven patients had bilateral non-palpable intraabdominal testes.

There were three patients with blind ending vas deference. No further surgery was applied to these patients.

All of the Group 1 patients required single-stage surgery. Thirty-three of Group 1 patients undergo orchiectomy because atrophic testes determined during diagnostic laparoscopy. Laparoscopic orchiectomy applied to two patients because of high localization of testes. Remain 31 patients required inguinal orchiectomy. There was 25 patients undergoing orchidopexy in Group 1. Laparoscopic orcidopexy applied in two patients which had high localized testes. Transition to open inguinal orchidopexy required in 23 patients because of entrance of testes to internal inguinal ring detected during diagnostic laparoscopy.

Eleven of 73 patients (Group 2) managed with two-staged surgery. After diagnostic laparoscopy as a first stage testes brought within the inguinal ring in all patients. After six months seven of Group 2 patients managed by open inguinal orchidopexy. Four testes required orchiectomy as a result of atrophy. Two of orchiectomies accomplished by inguinal and remain two patient's orchiectomy by scrotal incision due to the position of testes during physical examination.

There was a one patient that undergone three staged orchiopexy. Testis size was smaller compared with contralateral testis. As a first stage testes brought down to the inguinal canal. High scrotal localized testis achieved as a result of a second step surgery. After 18 months of follow-up orchiectomy was applied due to no sign of catch-up growth and previous atrophy.

There were $16(21.9 \%)$ high localized testes patients in study. Two of them from Group 1 detected to be atrophic during diagnostic laparoscopy and orchiectomy was done. 


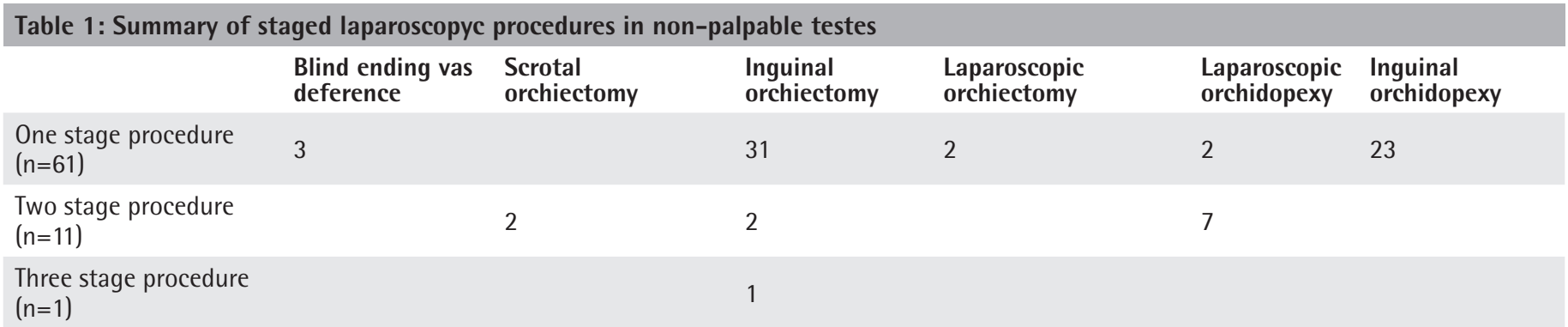

Other two patients either from Group 1 undergone single-stage laparoscopic orchidopexy. Of 16 patients seven undergone inguinal orchiopexy as a second-stage procedure. Remain four patients from Group 2 undergone inguinal and scrotal orchiectomy as a second-stage procedure (Table 1).

There was 54 low localized testes: Twenty-three and 31 patients from Group 1, Group 2 respectively. Manipulation or assistance of laparoscopic grasper required during diagnostic laparoscopy before transition to inguinal orchiopexy in 23 patients from Group 1. There were 54 (73.9\%) low localized testes patients in study. All of the patients were from Group 1. Thirty-one low localized testes underwent inguinal orchiectomy as a visualization of spermatic chord entrance to the internal inguinal ring confirmed by diagnostic laparoscopy. Twentythree patients from Group 1 required inguinal orchidopexy because of low localization of testes either (Table 2).

Pathological findings of 38 orchiectomy material were as atrophic testes in 19 and fibrotic tissue in remain 19 cases.

\section{Discussion}

Laparoscopy is an effective approach in diagnosis and management of non-palpable testes in children. In our study 73 patients underwent diagnostic laparoscopy. According to findings diagnostic laparoscopy applied successfully in 32 (43.8\%) orchidopexy, 38 (52\%) orchiectomies.

Management of palpable UDT have high success rate when it is performed through a small inguinal incision. Despite palpable testes, surgical intervention of non-palpable testes is challenging. Testes may be in intraabdominal area, intracanalicular, superficial pouch, ectopic side or vanished due to vascular compromise (10). So before definitive decision it is important to determine whether a testes present or not $(11,12)$. Diagnostic laparoscopy is most easiest and accurate tool used for this purpose (13). It can serve as diagnostic and therapeutic approach for non-palpable testes. Use of diagnostic laparoscopy after inguinal exploration is preferred by some authors (14). In all patients in our study group diagnostic laparoscopy preferred as a first step of surgical management. After observation of all quadrants especially inguinal region by diagnostic laparoscopy following anatomical findings can be detected: Peepin testes

$\begin{array}{llll}\begin{array}{l}\text { Table 2: Categorization of testes localizations and applied } \\ \text { procedures }\end{array} & \begin{array}{l}\text { High localised } \\ \text { testes } \\ \mathbf{n = 1 6} \text { (21.9\%) }\end{array} & \begin{array}{l}\text { Low localised } \\ \text { testes } \\ \mathbf{n = 5 4} \text { (73.9\%) }\end{array} & \begin{array}{l}\text { Blind ended } \\ \text { vas deference }\end{array} \\ \mathbf{n = 3} \text { (4.1\%) }\end{array}$

$(10 \%)$, blind ending spermatic vessels $(10 \%)$, intraabdominal testes $(40 \%)$. Thirty-one percentages of testes used to be peepin, $4.1 \%$ of patients had blind ending spermatic vessel and $64 \%$ of patients had intraabdominal testes in our study. This findings lead surgeon to a certain decision about which approach to use: One or two staged laparoscopic orchidopexy or orchiectomy, inguinal orchiopexy or laparoscopy assisted orchidopexy $(8,9)$. In a presented study all non-palpable testes patients undergone laparoscopy assisted orchidopexy. Anatomical findings and of testes were as following: Thirty-one percent of testes used to be peepin, $4.1 \%$ of patients had blind ending spermatic vessel and $64 \%$ of patients had inraabdominal testes. Intraabdominal testes 
are classified as low and high according to their appearance to internal ring $(1,2)$. This distance between intraabdominal testes and inguinal ring also determines surgeons approach. All patients underwent diagnostic laparoscopy in presented study. Laparoscopy is a feasible diagnostic tool for determining of testes localization in patients with non-palpable testes. It is also gives a great opportunity for avoidance of unnecessary inguinal incision in vanishing testes which causes acceptable cosmetic results.

Laparoscopyc manipulation of testes needed in four patients from Group 1. In seven patients from Group 2 testes brought down to inguinal canal after laparoscopic dissection. There are significantly high amount of studies in literature comparing different management techniques for non-palpable testes (15). According to the literature and our clinical experience we prefer do not transect testicular vessels during orchidopexy (16). Of total 32 orchidopexies performed in our study 7 patients required two staged surgery. As a first step testes brought down to inguinal canal after careful dissection of vas deference and vessels from peritonum without transection of vessels. In a second stage standard inguinal orchidopexy applied to all patients successfully. In a follow-up of patients size and localization of testes determined by physical examination. No atrophy determined in these patients.

\section{Conclusion}

Laparoscopic assistance in management of non-palpable testes not only leads to determination of localization and decision of next step procedure, but also avoids unnecessary surgical attempts.

\section{Ethics}

Ethics Committee Approval: Ankara University Faculty of Medicine, Clinical Research Ethics Committee approval was provided for the study (approval no: 09-723-1).

Informed Consent: Retrospective study.

Peer-reviewed: Externally peer-reviewed.

\section{Authorship Contributions}

Surgical and Medical Practices: G.E., U.A., A.G., M.B.K., A.Y., M.Ç., G.G., Concept: G.E., U.A., A.G., M.B.K., A.Y., M.Ç., G.G.,
Design: G.E., U.A., A.G., M.B.K., A.Y., M.Ç., G.G., Data Collection or Processing: G.E., U.A., A.G., M.B.K., A.Y., M.Ç., G.G., Analysis or Interpretation: G.E., U.A., A.G., M.B.K., A.Y., M.Ç., G.G., Literature Search: G.E., U.A., A.G., M.B.K., A.Y., M.Ç., G.G., Writing: G.E., U.A., A.G., M.B.K., A.Y., M.Ç., G.G.

Conflict of Interest: No conflict of interest was declared by the authors.

Financial Disclosure: The authors declared that this study received no financial support.

\section{References}

1. Kim J, Min GE, Kim KS. Laparoscopic orchiopexy for a nonpalpable testis. Korean J Urol. 2010;51:106-110.

2. Scorer CG. The Descent of the Testis. Arch Dis Child. 1964;39:605-609.

3. Levitt SB, Kogan SJ, Engel RM, et al. The impalpable testis: a rational approach to management. J Urol. 1978;120:515-520.

4. Choi KY, Park TH, Kim KS. Laparoscopic orchiopexy for intra-abdominal testis: complications and technical aspects. Korean J Urol 2000;41:420-424.

5. Dar SA, Bali RS, Zahoor $Y$, et al. Undescended Testes and Laparoscopy: Experience from the Developing World. Adv Urol. 2018;2018:1620470.

6. Smolko MJ, Kaplan GW, Brock WA. Location and fate of the nonpalpable testis in children. J Urol. 1983;129:1204-1206.

7. Denes F, Saito FJ, Silva FA, et al. Laparoscopic diagnosis and treatment of nonpalpable testis. Int Braz J Urol. 2008;34:329-334.

8. Jamalalail YA, Guerra LA, Leonard MP. Selective use of laparoscopy in nonpalpable undescended testes. Urol Ann. 2016;8:81-83.

9. Lamesch A. L'anorchidie unilatérale ou monorchidie [Unilateral anorchidism or monorchidism]. Chirurgie. 1992;118:328-332.

10. Tennenbaum SY, Lerner SE, McAleer IM, et al. Preoperative laparoscopic localization of the nonpalpable testis: a critical analysis of a 10-year experience. J Urol. 1994;151:732-734.

11. Wayne C, Chan E, Nasr A; Canadian Association of Paediatric Surgeons Evidence-Based Resource. What is the ideal surgical approach for intraabdominal testes? A systematic review. Pediatr Surg Int. 2015;31:327-338.

12. Cortesi N, Ferrari P, Zambarda E, et al. Diagnosis of bilateral abdominal cryptorchidism by laparoscopy. Endoscopy. 1976;8:33-34.

13. Chan $\mathrm{KW}$, Lee $\mathrm{KH}$, Wong $\mathrm{HY}$, et al. Use of laparoscopy as the initial surgical approach of impalpable testes: 10-year experience. World J Clin Pediatr. 2015:4:155-159.

14. Chandrasekharam W. Laparoscopy vs inguinal exploration for nonpalpable undescended testis. Indian J Pediatr. 2005;72:1021-1023.

15. Docimo SG. The results of surgical therapy for cryptorchidism: a literature review and analysis. J Urol. 1995;154:1148-1152.

16. Daher $\mathrm{P}$, Nabbout $\mathrm{P}$, Feghali J, et al. Is the Fowler-Stephens procedure still indicated for the treatment of nonpalpable intraabdominal testis? J Pediatr Surg. 2009;44:1999-2003. 